\title{
EXPANSIVE SOIL STABILIZATION USING MUD (LAPINDO) AND ASPHALT EMULSION
}

\author{
Resti Meysita Pramaesti ${ }^{1 *}$, Syahril², Hendry ${ }^{2}$ \\ ${ }^{1}$ Master of Applied Infrastructure Engineering, Politeknik Negeri Bandung 40012 \\ Corresponding Author Email: restymeysitap@gmail.com \\ ${ }^{2}$ Departement Of Civil Engineering, Politeknik Negeri Bandung 40012
}

\begin{abstract}
Most of Gedebage area consist of expansive soil and always greatly induce disturbance to structure of foundation. Nature properties of expansive soil is a high plasticity value, low soil shear strength, high swelling, and large potential for shrinkage. One solution for soil improvement is to use an additional material to stabilize this soil. Additional material uses locked emulsion asphalt $8 \%$ and mud from Lapindo area in variation of $3 \%, 6 \%, 9 \%$ and $12 \%$. The results of testing the physical and mechanical properties after stabilization indicates increasing of density value around $68 \%$. Plasticity index tends to decrease until $10 \%$ from CBR test. CBR values with curing time of 14 days are $8.1 \%$ for unsoaked and by $4.6 \%$ for soaked conditions.
\end{abstract}

Keyword: Stabilization, Lapindo Mud, Asphalt Emulsion

\section{INTRODUCTION}

This study aims to determine and obtain several parameters from the results of physical and mechanical properties testing aimed at stabilizing expansive soil conditions using a mixture of and asphalt emulsion and Lapindo mud [1]. Design of sub-structure is very influenced by size and type of soil foundation where the foundation structure embedded [2] . Mud Lapindo area at Sidoarjo district east Java Province, Indonesia is the side impact produced of oil drilling [3]. Discharge of mudflow reaches $120,000 \mathrm{~m}$ per day and flooded of eight villages. This mud still comes out in small volume bursts [4]. Some physical properties have been studied in the detail [5] the results show texture of the clay $62 \%$, dust $35 \%$ and sand $3 \%$. Sidoarjo mud soil has a cation exchange capacity (CEC) with $42.58 \mathrm{me} / 100 \mathrm{~g}$ Ref. Lapindo mud contains chemicals, one of which is silicate mineral (SiO2) which is higher than cement and lime $(\mathrm{CaO})$. The silica content is a filler between inter-particles. Meanwhile, the lime content is a binder between outer particles. Normally, mud content is used as cement ingredients [6] [7]. Soil stabilization is one of the efforts aimed to improve the nature properties of soil foundation with the additional materials in increasing shear strength [8]. One of additional material is selected mud from Lapindo and asphalt emulsion to stabilize the expansive soil [9].

Stabilization is a process in which an additive or reagent is mixed with waste to minimize the rate of transfer of contaminants present in the waste to the environment and to reduce the level of toxicity of the waste. From the case of the Lapindo mudflow that occurred The hot mudflow at the drilling site owned by PT Lapindo Brantas that occurred since May 29, 2006 resulted in a number of villages in Sidoarjo, East Java The chemical content of the Lapindo Mud such as $\mathrm{SiO} 253.08 \%$ and CaO 2.07\%, where the silica content functions as a filler material from the test results [10] and has a fairly good effect in increasing the bearing capacity of expansive soils. Therefore, one waste that will be used as a mixing material for expansive soil is Lapindo Mud which aims to increase the carrying capacity of expansive soil.

The process of taking silica content in Lapindo mud can be done by chemical processes and SEM testing to find out how much silica content in the mud.

\section{RESEARCH METHOD}

Research was conducted at the Laboratory Test Material to find out stabilization value with additional material from Lapindo mud and emulsified asphalt. Figure 1 shows the flowchart of this study. 


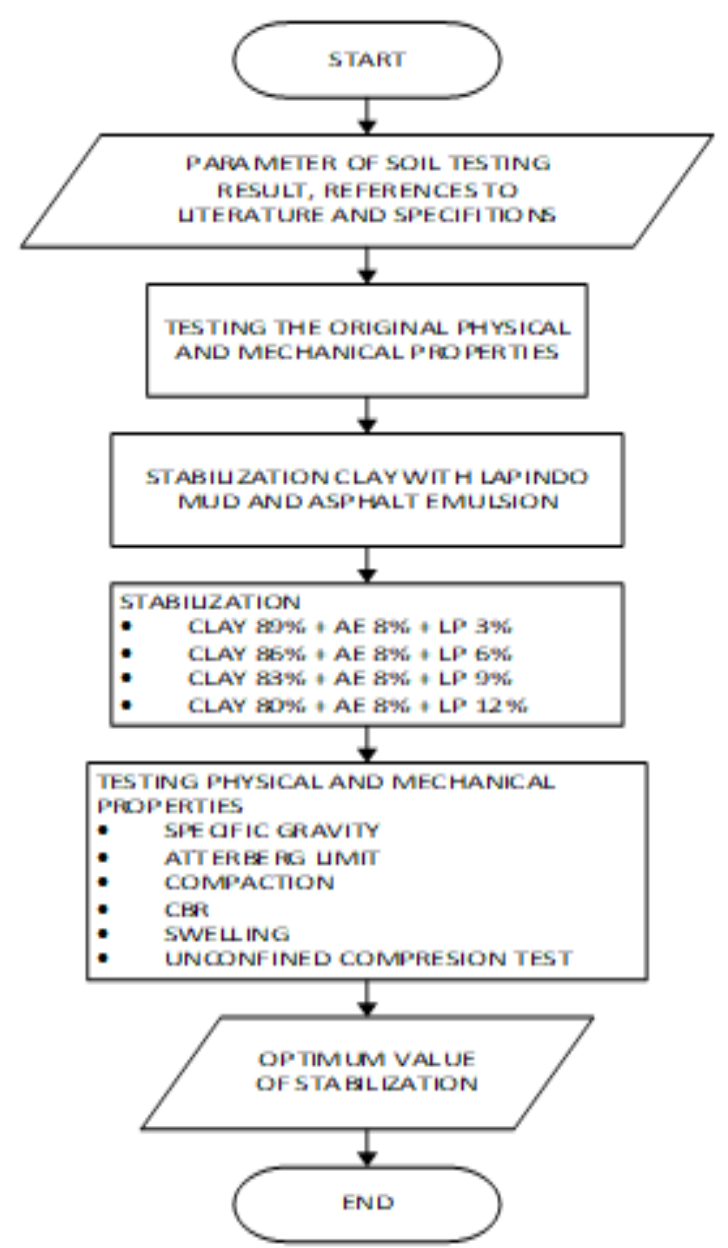

Figure 1. Testing methodology in the laboratory

\section{RESULT}

\subsection{Test Result of Mixed Subgrade Physical Characteristics}

Table 1 shows the test results of soil properties and some variables to determine the optimum content of additional material to expansive soil.

Table 1 Physical Properties Testing

\begin{tabular}{|c|c|c|c|c|c|c|c|c|c|}
\hline \multicolumn{2}{|c|}{ Index Properties } & \multirow[t]{2}{*}{ Symbol } & \multirow[t]{2}{*}{ Unit } & \multirow[t]{2}{*}{ Clay } & \multirow{2}{*}{$\begin{array}{c}\text { Lapindo } \\
\text { Mud }\end{array}$} & \multicolumn{4}{|c|}{ Variable } \\
\hline & & & & & & 1 & 2 & 3 & 4 \\
\hline 1 & Atterberg Limit & & & & & & & & \\
\hline 1.1 & Plastic Limit & PL & $\%$ & 38 & 21 & 32.67 & 26.3 & 30.9 & 22.7 \\
\hline 1.2 & Liquid Limit & LL & $\%$ & 85 & 48 & 48.39 & 43.0 & 40.4 & 40.4 \\
\hline 1.3 & Plasticity Index & PI & $\%$ & 47 & 27 & 15.72 & 16.6 & 9.5 & 17.7 \\
\hline 1.4 & Shrinkage Limit & SL & $\%$ & & 14 & 8.05 & 14.7 & 16.5 & 11.1 \\
\hline 2 & specific gravity & Gs & & 2.59 & 1.15 & 2.05 & 2.08 & 2.03 & 3.46 \\
\hline 3 & Grain Size & & & & & & & & \\
\hline 3.1 & Gravel & $\mathrm{G}$ & $\%$ & 0 & - & - & - & - & - \\
\hline 3.2 & Sand & Symbol & $\%$ & 4.62 & - & - & - & - & - \\
\hline 3.3 & Silt & $\mathrm{M}$ & $\%$ & 39.38 & - & - & - & - & - \\
\hline 3.4 & Clay & $\mathrm{C}$ & $\%$ & 51 & - & - & - & - & - \\
\hline
\end{tabular}

\section{Information:}

Variable $1=3 \%$ Lapindo Mud

Variable $2=6 \%$ Lapindo Mud

Variable $3=9 \%$ Lapindo Mud

Variable $4=12 \%$ Lapindo Mud 


\subsection{Mechanical properties test results}

\section{Compaction}

Results of the compaction test is shown that the optimum water content decreases according to increase percentage of Lapindo mud. Can be seen in Figure 2 below:

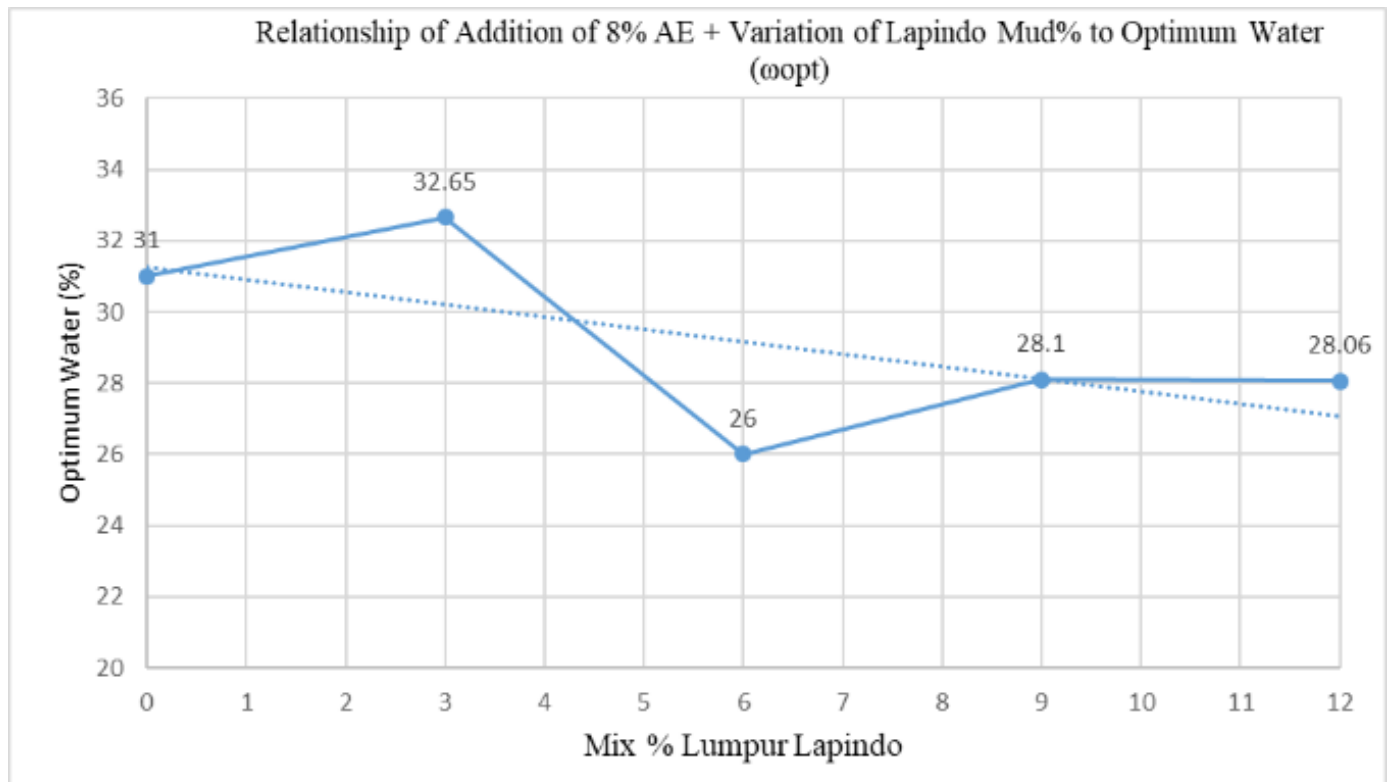

Figure 2 curve of optimum moisture content Addition of\% Asphalt Emulsion + Variation of\% Lapindo Mud Mixture

The compaction test shows that the dry weight volume increases with the addition of Lapindo mud.

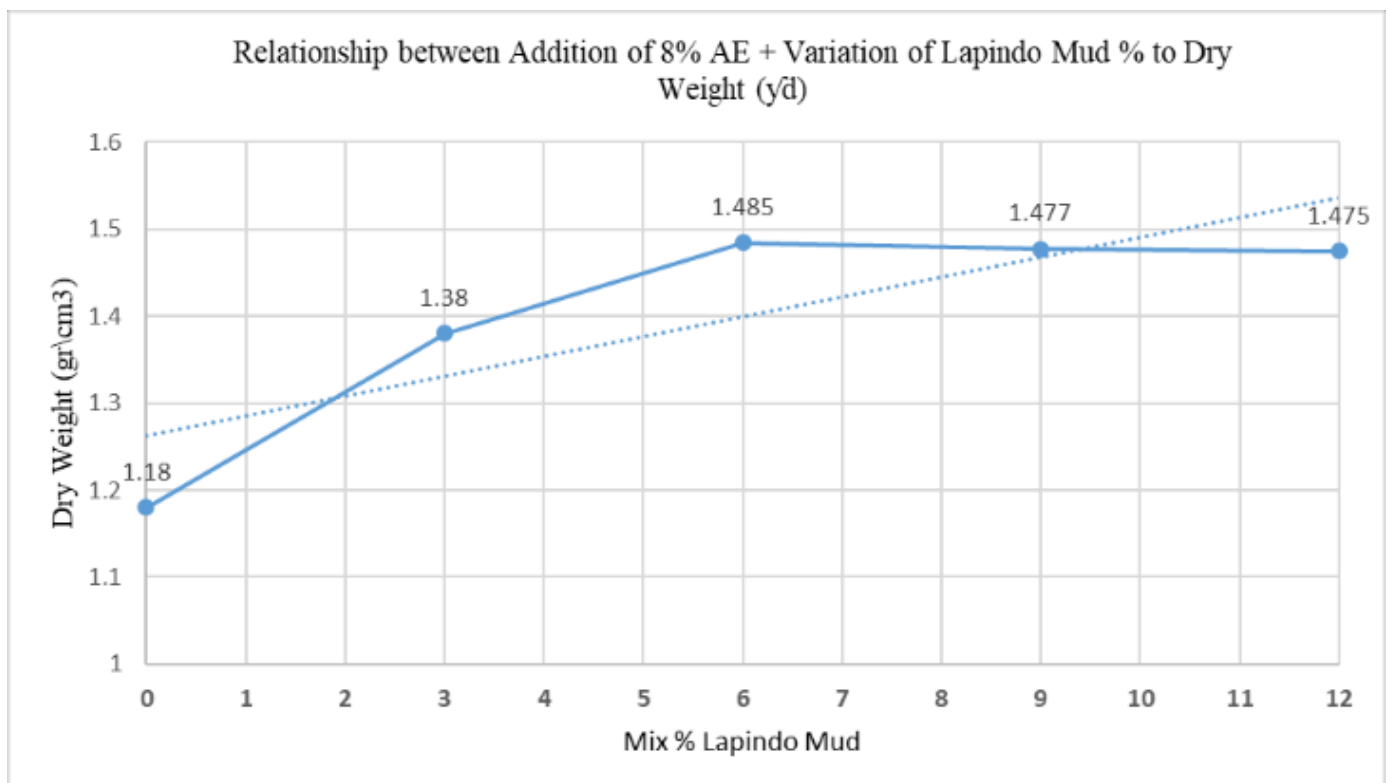

Figure 3 curve of Mixture Dry Weight $\left(\gamma_{\mathrm{d}}\right)$ Addition of\% Asphalt Emulsion + Variation of\% Lapindo Mud

From the results of the dry weight compaction test $\left(\gamma_{\mathrm{d}}\right)$ in the image above, this shows that in mixing 0 , The dry weight value $\left(\gamma_{\mathrm{d}}\right)$ is $1.18 \mathrm{gr} / \mathrm{cm}^{3}$, while the locked emulsion asphalt mixture variable is $8 \%$ and the Lapindo mud mix varies. Then the dry weight $\left(\gamma_{\mathrm{d}}\right)$ value of the $3 \%$ Lapindo mud is $1.38 \mathrm{gr} / \mathrm{cm}^{3}$, at $6 \%$ it is $1.485 \mathrm{gr} / \mathrm{cm}^{3}$, the $9 \%$ mixture is $1.477 \mathrm{gr} / \mathrm{cm}^{3} . \mathrm{obtained} \mathrm{dry}$ weight $\left(\gamma_{\mathrm{d}}\right)$ of $1.475 \mathrm{gr} / \mathrm{cm}^{3}$.

\section{Testing CBR (California Bearing Ratio)}

Plastic Index decrease until below $11 \%$ with the additional Lapindo mud from the CBR test. 
Table 2 CBR test results from the variable mixture of asphalt emulsion and Lapindo mud

\begin{tabular}{ccccccc}
\hline & Technical Properties & Days & Symbol & Unit & $\begin{array}{c}\text { Expansive } \\
\text { Soil }\end{array}$ & $\begin{array}{c}\text { Variable } \\
\mathbf{3}\end{array}$ \\
\hline $\mathbf{1}$ & Unsoaked & & & & & 4.5 \\
\hline $\mathbf{1 . 1}$ & Curing & 0 & CBR design & $\%$ & 4.1 & 6 \\
\hline $\mathbf{1 . 2}$ & Curing & 3 & CBR design & $\%$ & - & 6.9 \\
\hline $\mathbf{1 . 3}$ & Curing & 7 & CBR design & $\%$ & - & 8.1 \\
\hline $\mathbf{1 . 4}$ & Curing & 14 & CBR design & $\%$ & - & \\
\hline $\mathbf{2}$ & & & & & & 2.1 \\
\hline $\mathbf{2 . 1}$ & Curing & 0 & CBR design & $\%$ & 1.8 & 2.7 \\
\hline $\mathbf{2 . 2}$ & Curing & 3 & CBR design & $\%$ & - & 3 \\
\hline $\mathbf{2 . 3}$ & Curing & 7 & CBR design & $\%$ & - & 4.6 \\
\hline $\mathbf{2 . 4}$ & Curing & 14 & CBR design & $\%$ & - & - \\
\hline
\end{tabular}

In table 2, the results of unsoaked and soaked CBR showed that the percentage value of variable 3 continued to increase with curing time compared to expansive soil with the percentage of unsoaked CBR values of $4.1 \%$ and $1.8 \%$ of Soaked.

\section{Swelling}

Swelling potential value below the optimum moisture content is taken from the index plasticity tests. This study was conducted to determine how much swelling percentage and Expansive Soil mixtures of Asphalt emulsion with 9\% Lapindo Mud.

Table 3 Result Swelling Stabilization Materials

\begin{tabular}{cccccc}
\hline \multicolumn{2}{c}{ Technical Properties } & Days & Unit & $\begin{array}{c}\text { Expansive } \\
\text { Soil }\end{array}$ & Variable \\
\hline $\mathbf{1 . 1}$ & Curing & 0 & $\%$ & 3.37 & $\mathbf{3}$ \\
\hline $\mathbf{1 . 2}$ & Curing & 3 & $\%$ & - & 2.7 \\
\hline $\mathbf{1 . 3}$ & Curing & 7 & $\%$ & - & 2.53 \\
\hline $\mathbf{1 . 4}$ & Curing & 14 & $\%$ & - & 2.33 \\
\hline
\end{tabular}

Table 3 shows that the value of swelling test specimen volume (Swelling) Mix 3 at 0 days curing time was $2.7 \%$ decreased by $1.7 \%$ at 3 days curing time and then dropped back to $0.2 \%$ at 7 days curing time and at 14 days curing time decreased also $0.43 \%$ or decreased by $99.92 \%$ from the 0-day curing time.

\section{Unconfined Compression $\left(q_{u}\right)$}

Table 4 Result Testing Unconfined Compression $\left(q_{u}\right)$

\begin{tabular}{|c|c|c|c|c|c|c|}
\hline \multirow{2}{*}{ Technical Properties } & \multirow{2}{*}{ symbol } & \multirow{2}{*}{ unit } & \multicolumn{4}{|c|}{ Variable } \\
\hline & & & 1 & 2 & 3 & 4 \\
\hline 1. & Unc & ined Com & ession ( & CS) & & \\
\hline Curing 0 Days & $\mathrm{q}_{\mathrm{u}}$ & $\mathrm{Kg} / \mathrm{cm}^{2}$ & 5.552 & 4.995 & 3.930 & 3.366 \\
\hline Curing 3 Days & $\mathrm{q}_{\mathrm{u}}$ & $\mathrm{Kg} / \mathrm{cm}^{2}$ & 6.530 & 6.329 & 5.147 & 4.501 \\
\hline Curing 7 Days & $\mathrm{q}_{\mathrm{u}}$ & $\mathrm{Kg} / \mathrm{cm}^{2}$ & 7.465 & 7.475 & 6.559 & 5.795 \\
\hline Curing 14 Days & $\mathrm{q}_{\mathrm{u}}$ & $\mathrm{Kg} / \mathrm{cm}^{2}$ & 6.998 & 6.649 & 6.343 & 6.1261 \\
\hline
\end{tabular}




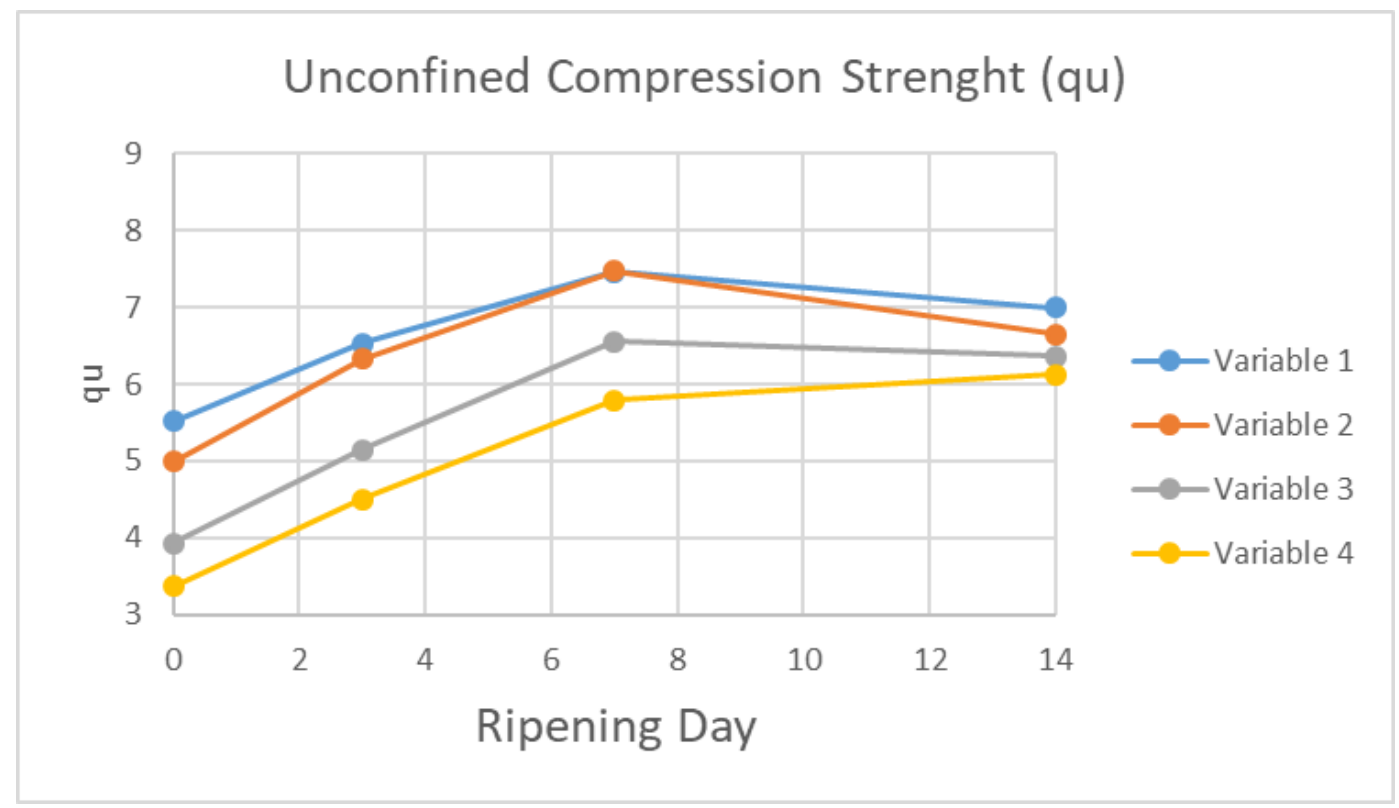

Figure 4 Soil compressive strength value curve

Graph of figure 4 In the use of soil compressive strength, this is one of the methods used to evaluate the performance of soil stabilization, and the value of free compressive strength is one of the main parameters that can be applied in planning the design of a project for earthworks [11]. the value of compressive strength, the longer the curing time, the value of the free compressive strength increases.

\section{CONCLUSION}

Based on the results of tests carried out in the laboratory, from the results of the compaction test by adding a mixture of asphalt emulsion material and Lapindo mud. From the results of soil compaction testing, the optimum dry weight (yd) value in the $12 \%$ Lapindo mud mixture is $1.475 \mathrm{gr} / \mathrm{cm} 3$. Meanwhile, the optimum water content value ( $\omega \mathrm{opt}$ ) was obtained in the $3 \%$ Lapindo mud mixture of $32.65 \%$. For the CBR test, variable 3 is taken because it has a significant plasticity index value, which is less than $10 \%$. The CBR value for unsoaked was $8.1 \%$ and $4.6 \%$ for soaked. Meanwhile, from the test results of the four Unconfined Compression Test (UCS) variables, the value of the independent compressive strength continued to increase up to 7 days of curing time, while at 14 days of curing it decreased.

\section{ACKNOWLEDGMET}

This opportunity to thank all faculty Civil Engineering Department of Politeknik Negeri Bandung for the support.

\section{REFERENCES}

[1] A. Patel, Geotechnical investigations and improvement of ground conditions, 2019.

[2] I. D. Kurniwan, "Pengaruh Variasi Jarak dan Panjang Deep Soil Mixing (DSM) 15\% Fly Ash Diameter 3cm Berpola Panels Terhadap Daya Dukung," Pengaruh Variasi Jarak dan Panjang Deep Soil Mixing (DSM) 15\% Fly Ash Diameter $3 \mathrm{~cm}$ Berpola Panels Terhadap Daya Dukung , 2015.

[3] I. W. C. \&. A. W. Wiguna, "Lapindo Mudflow Mitigation," 2009.

[4] D. A. B.D. Krisnayanti, "Characteristics of Lusi mud volcano and its impacts on the Porong River," JOURNAL OF DEGRADED AND MINING LANDS MANAGEMENT, no. ISSN: 2339-076X, Volume 1, Number 4 (July 2014): 207$210,2014$.

[5] N. Brady, "The Nature and Properties of Soil," 1990.

[6] M. N. B. D. a. G. A. Müller H, "A review of content-based image Retrieval systems in medical applications-clinical benefits and future directions," Medical Informatics, 2004.

[7] Aristianto, " Preliminary examination of Sidoarjo Mud for Ceramic Products, Balai Besar Keramik Bandung, Indonesia.," 2006.

[8] A. Ismail, "Pengaruh Variasi Jarak dan Panjang Kolom," Pengaruh Variasi Jarak dan Panjang Kolom , 2016.

[9] h. Susilo, Y. Zaika and Harimurti, "Pengaruh Jarak dan Panjang Kolom Dengan Diameter 4 Cm Pada Stabilisasi Tanah Lempung Ekspansif Menggunakan Metode DSM Berpola Single Square Terhadap Daya Dukung Tanah," Pengaruh 
Jarak dan Panjang Kolom Dengan Diameter 4 Cm Pada Stabilisasi Tanah Lempung Ekspansif Menggunakan Metode DSM Berpola Single Square Terhadap Daya Dukung Tanah.

[10] Syahril, I. Suratman, B. S. Subagio and Siegfried, Pengaruh Stabilisasi Aspal Emulsi terhadap Karakteristik Lapisan Tanah Dasar yang Berasal Dari Tanah Lunak, 2011.

[11] N. Yarbasi, E. Kalkan and S. Akbulut, "Modification of the geotechnical properties, as influenced by freeze-thaw, of granular soils with Waste Additivies," 2007.

[12] Z. Zhang and M. Tao, "Durability of cement stabilized low plasticity," Journal of Geotechnical and Geoenvironmental Engineering 134, pp. 134 (2), 203-213, 2008.

[13] "The influence of freeze-thaw cycles on the unconfined compresssive strenght of fiber-reinforced clay," Cold Regions Science and Thenoglogy, pp. 61 (2-3) , 125-131, 2010.

[14] M. \&. S. Al Imam, "Pengaruuh Kadar Air dilapangan dan Ratio Air - Fly ash Terhadap Kekuatan dan Pengembangan Tanah Ekspansif untuk metode DSM (Deep Soil mixig)," 2017. 